\title{
Selenium influences growth via thyroid hormone status in broiler chickens
}

\author{
He Jianhua*, Akira Ohtsuka, and Kunioki Hayashi $†$ \\ Department of Biochemical Science and Technology, Faculty of Agriculture, Kagoshima University, 1-21-24 Korimoto, \\ Kagoshima 890-0065, Japan
}

(Received 25 September 1998 - Revised 29 February 2000 - Accepted 13 March 2000)

\begin{abstract}
As there is a possibility that Se influences the growth of animals via thyroid hormone metabolism, the following three experiments were undertaken in order to determine the effects of dietary Se on growth, skeletal muscle protein turnover and thyroid hormone status in broiler chickens. Broiler chickens were raised on a Se-deficient diet until $12 \mathrm{~d}$ of age and then used for the experiments. In Experiment 1, twenty-eight birds were randomly assigned to four groups and fed purified diets with the following amounts of Se supplementation: $0 \cdot 0,0 \cdot 1,0.3$ and $0.5 \mathrm{mg}$ $\mathrm{Se} / \mathrm{kg}$ diet. Dietary Se supplementation significantly increased plasma 3,5,3'-triiodothyronine (T3) concentration and improved growth, while plasma thyroxine (T4) concentration was decreased. In Experiment 2, twenty-eight birds were assigned to four groups and fed either a Sedeficient diet or a Se-supplemented diet $(0.3 \mathrm{mg} \mathrm{Se} / \mathrm{kg}$ diet $)$ with or without the supplementation of iopanoic acid, a specific inhibitor of $5^{\prime}$-deiodinase $(5 \mathrm{mg} / \mathrm{kg}$ diet $)$. The growth was promoted and feed efficiency was improved by dietary Se supplementation as was also observed in Experiment 1. However, this effect of Se was halted by iopanoic acid supplementation. Hepatic 5 -deiodinase activity was elevated by Se and inhibited by iopanoic acid. In Experiment 3, birds were fed on the following diets to show that Se influences growth of birds via thyroid hormone metabolism: Se-deficient diet, Se-supplemented diets $(0.1$ and $0.3 \mathrm{mg} / \mathrm{kg})$ and T3 supplemented diets $(0 \cdot 1$ and $0.3 \mathrm{mg} / \mathrm{kg}$ diet $)$. Lower dietary T3 supplementation $(0 \cdot 1 \mathrm{mg} / \mathrm{kg}$ diet $)$ resulted in growth promotion similar to Se supplementation, while higher level of T3 caused growth depression. Furthermore, it was observed that the rate of skeletal muscle protein breakdown tended to be increased by Se similarly to the effect of T3. In conclusion, it was shown in the present study that Se deficiency depresses growth of broilers by inhibiting hepatic $5^{\prime}$-deiodinase activity which causes lower plasma T3 concentration.
\end{abstract}

Selenium: Thyroid hormone: $5^{\prime}$-Deiodinase: Growth

Since Se was established as being an essential micronutrient in 1957 (Schwartz \& Foltz, 1957), most studies concerning Se have concentrated on the role of glutathione peroxidase (GSHPx), which catabolizes $\mathrm{H}_{2} \mathrm{O}_{2}$ and other organic hydroperoxides (Burk, 1989). In 1986, Jensen et al. (1986) observed that dietary Se affects thyroid hormone metabolism, and it was then observed by Beckett et al. (1987) that plasma 3,5,3'-triiodothyronine (T3) is produced by $5^{\prime}$-deiodination of thyroxine (T4) in non-thyroidal tissues, particularly the liver and kidney. The reaction is catalysed by type I iodothyronine deiodinase (5'-ID) (Beckett et al. 1992), which was verified as being a selenoenzyme (Arthur et al. 1990, 1992, 1993; Berry et al.
1991; Beckett et al. 1992; Kohrle et al. 1992). Brain, pituitary gland and brown adipose tissues contain a different selenoenzyme catalysing $5^{\prime}$-deiodinations, type II deiodinase (Davey et al. 1995). It has been reported that Se deficiency alters both thyroid hormone synthesis in the thyroid gland and the activity of tissue specific $5^{\prime}$-ID in rats (Kohrle et al. 1992). Hepatic 5'-ID activity in the Sedeficient rat is 10-fold lower than that of the Sesupplemented rat (Beckett et al. 1992) and plasma T3 concentration is significantly lower than that of the normal rat (Beckett et al. 1987). On the other hand, Arthur \& Beckett (1994) have reported that the $5^{\prime}$-ID activity in the thyroid of Se-deficient rats is four times greater than in

\footnotetext{
Abbreviations: GSHPx, glutathione peroxidase; 5'-ID, type I iodothyronine deiodinase; MH, N${ }^{\top}$-methylhistidine; T3, 3,5, $3^{\prime}$-triiodothyronine; T4, thyroxine.

* Present address: College of Animal Science and Technology, Human Agricultural University, Changsha, Hunan Province, P.R. China.

$\uparrow$ Corresponding author: Dr Kunioki Hayashi, fax +8199285 8652, email hayashi@chem.agri.kagoshima-u.ac.jp
} 
Se-sufficient rats. Chanoine et al. (1993) have reported that the thyroid gland is a major source of circulating T3 in rats, accounting for approximately $55 \%$ of total T3 production. In any case, T4 is synthesized exclusively in the thyroid gland, and thought to be a prohormone requiring activation by $5^{\prime}$-monodeiodination to form biologically active $\mathrm{T} 3$. The contribution of intrathyroidal conversion of $\mathrm{T} 4$ to $\mathrm{T} 3 \mathrm{to} \mathrm{T} 3$ homeostasis appears to be important, but the exact contribution remains to be determined.

It is well documented that the thyroid hormones play important roles in growth and protein turnover (Hayashi et al. 1991; Hayashi, 1993), therefore, Se deficiency might affect protein turnover followed by growth retardation, as $\mathrm{T} 3$ production is impaired.

In the present study, three experiments were carried out to investigate the effect of dietary Se on thyroid hormone status, growth and skeletal muscle protein breakdown in broiler chickens. The first experiment was designed to clarify the relation between Se level, plasma thyroid hormone and growth. To further characterize the effects of dietary Se on thyroid hormone metabolism in the second experiment, we used iopanoic acid, a deiodinase inhibitor, to prove that the effect is correlated with the change in $5^{\prime}$ ID activity. The third experiment was designed to compare the effect of dietary Se and dietary $\mathrm{T} 3$ on growth and skeletal muscle protein breakdown.

\section{Materials and methods}

\section{Animals and diets}

Experiment 1. A total of forty 1-d-old Arbor Acres male broiler chickens, obtained from a commercial hatchery (Kumiai Hina Center, Kajiki Kagoshima, Japan), were housed in an electrically-heated battery brooder and were given a Se-deficient diet for $12 \mathrm{~d}$ (Se-depletion period) with free access to deionized water. The Se-deficient diet was formulated according to the National Research Council (1994) and the composition is shown in Table 1. Twentyeight birds of similar body weight (199 (SEM 8) 8 g) were then selected and randomly assigned to one of four dietary treatments $(0 \cdot 0,0 \cdot 1,0.3$ or $0.5 \mathrm{mg} \mathrm{Se} / \mathrm{kg}$ diet $)$. Sodium selenite was used to supplement Se. The diets were given for $9 \mathrm{~d}$ starting at $12 \mathrm{~d}$ of age. All the birds were individually housed in a metabolism cage in a temperature-controlled room $\left(25^{\circ} \mathrm{C}\right)$ with free access to feed and deionized water. Body weight was measured on the 3rd, 6th and 9th day of the treatment period. Feed intake was recorded daily. At $21 \mathrm{~d}$ of age, all the birds were killed by decapitation and blood samples were collected into heparinized tubes and centrifuged at $1250 \mathrm{~g}$ for $15 \mathrm{~min}$ at $4^{\circ} \mathrm{C}$. The plasma samples were then stored at $-20^{\circ} \mathrm{C}$ until analysed.

Experiment 2. Forty birds were raised exactly as in Experiment 1 until $12 \mathrm{~d}$ of age. Then twenty-eight birds of similar body weight (about 238 (SEM 8) g) were selected and randomly assigned to one of four dietary treatments for $9 \mathrm{~d}(0$ or $0.3 \mathrm{mg} \mathrm{Se} / \mathrm{kg}$ diet, with or without $5 \mathrm{mg}$ iopanoic $\mathrm{acid} / \mathrm{kg}$ diet). Iopanoic acid was purchased from Sigma Chemical Co., (St Louis, MO, USA). The experiment was conducted in a similar way to Experiment 1 .
Table 1. Composition of the purified diet

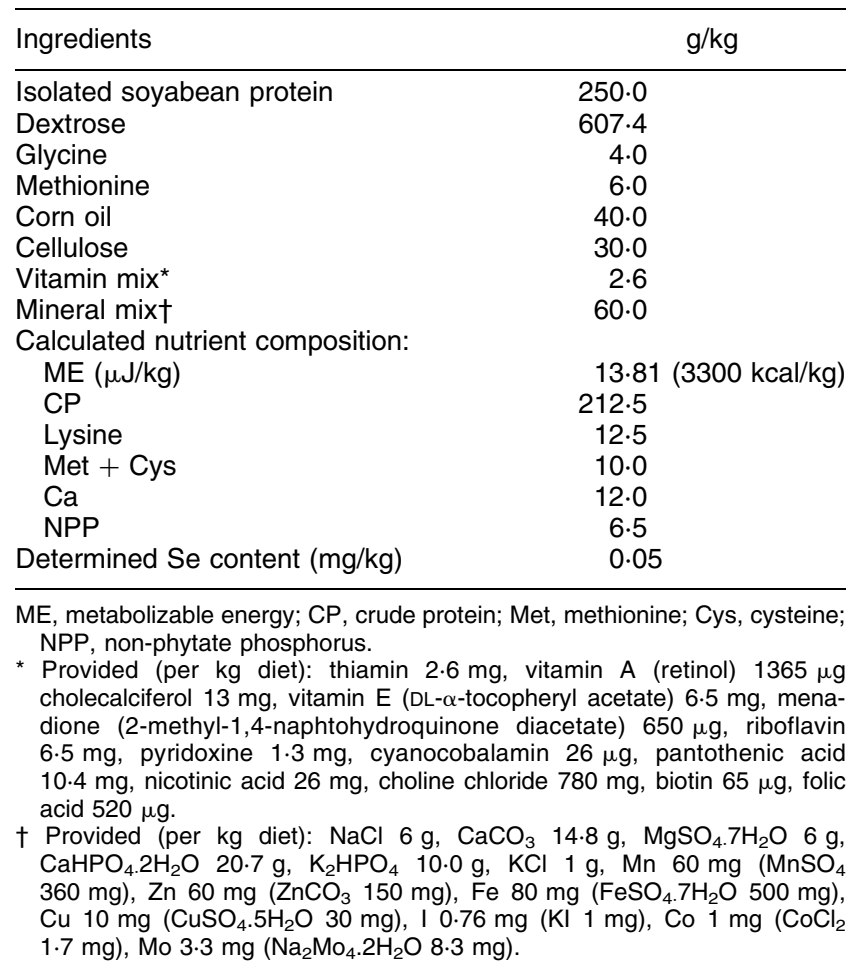

Experiment 3. The third experiment was conducted similarly to the previous experiments except excreta was collected to measure $\mathrm{N}^{\tau}$-methylhistidine $(\mathrm{MH})$ excretion which is an index of skeletal muscle protein breakdown. The birds were fed the Se-deficient diet for the first $12 \mathrm{~d}$ and thirty-five birds of similar body weight (about 232 (SEM 8) g) were selected and randomly assigned to one of five treatment groups: $0 \mathrm{mg} \mathrm{Se} / \mathrm{kg}$ diet; $0.1 \mathrm{mg} \mathrm{Se} / \mathrm{kg}$ diet; $0.3 \mathrm{mg} \mathrm{Se} / \mathrm{kg}$ diet; $0.1 \mathrm{mg} \mathrm{T} 3 / \mathrm{kg}$ diet; $0.3 \mathrm{mg} \mathrm{T} 3 / \mathrm{kg}$ diet. The excreta samples were collected for $2 \mathrm{~d}$ starting at $19 \mathrm{~d}$ of age. The collected samples were stored at $-20^{\circ} \mathrm{C}$ until analysed. At $21 \mathrm{~d}$ of age, all the birds were killed by decapitation and blood samples were collected as described in experiment 1 (p. 728). The chemicals were purchased from Nacalai Tesque Inc. (Kyoto, Japan) unless otherwise stated.

\section{Plasma glutathione peroxidase activity measurement}

Plasma GSHPx activity was measured by the modified method of Hawkes \& Kimberly (1990). The unit of activity was defined as the amount of enzyme required to prevent the reduction of $1 \mu \mathrm{mol}$ dichloroindophenol per min at $25^{\circ} \mathrm{C}, \mathrm{pH} 7 \cdot 8$. Each plasma sample $(1 \mathrm{ml})$ was preincubated with $0.8 \mathrm{ml} 2.3 \mathrm{mM}$-glutathione for $2.5 \mathrm{~min}$, then $0.8 \mathrm{ml}$ $1.5 \mathrm{~mm}$-peroxide was added and the enzyme reaction went on for $14 \mathrm{~min}$. Then, $0.8 \mathrm{ml} 0.68 \mathrm{mM}$-dichloroindophenol was added, reacted for $7 \mathrm{~min}$ and absorbance was determined with a double-beam spectrophotometer (UV150-02, Shimadzu Corporation, Kyoto, Japan) at $630 \mathrm{~nm}$. The unit shown in the present experiment can be converted to the unit reported by Paglia \& Valentine (1967) by multiplying by 167 . 


\section{Measurement of thyroid hormone}

Plasma T4 and T3 concentrations were measured by commercial kits. T4 concentration was measured by Enzymun-Test T4 (Boehringer-Mannheim, Mannheim, Germany) and T3 concentration was measured by Enzymun-Test T3, Elisa-Auto T3 (International Reagents Corporation, Kobe, Japan).

\section{Selenium content determination}

The plasma and liver Se content were determined by the fluorometric method (Bellanger, 1995). Samples were digested at $160^{\circ} \mathrm{C}$ for $150 \mathrm{~min}$ with a mixed digestion solution $\left(13 \mathrm{M}-\mathrm{HNO}_{3}-12 \mathrm{M}-\mathrm{HClO}_{4}(2: 1, \mathrm{v} / \mathrm{v})\right)$. The $\mathrm{pH}$ of digested solution was adjusted to $1 \cdot 0-1.5$ with $6 \mathrm{M}-\mathrm{NaOH}$, then a fluorescence derivative was made with $1 \mathrm{ml} 0.1 \%$ 2,3-diaminonaphthalene. The fluorescence compound was extracted with $2.0 \mathrm{ml}$ cyclohexane (Wako Pure Chemical Industry Ltd, Osaka, Japan), and was measured by F-2000 fluorescence spectrophotometer (Shimadzu Corporation) at excitation wavelength of $379 \mathrm{~nm}$ and emission wavelength of $521 \mathrm{~nm}$.

\section{Hepatic type I iodothyronine deiodinase activity measurement}

The hepatic $5^{\prime}$-ID activity was measured as the rate of radiolabelled I released from labelled reverse T3 $\left(3,3^{\prime}, 5^{\prime}\right.$ triiodo-L-thyronine) according to the method of Freeman \& McNabb (1991). The liver samples $(0.5 \mathrm{~g})$ were homogenized in three volumes ice-cold $50 \mathrm{mM}$-morpholinopropane sulfonic acid (Sigma Chemical Co.) buffer, containing $1 \mathrm{mM}-\mathrm{EDTA}$ at $\mathrm{pH} 7 \cdot 4$. The homogenate was centrifuged at $1000 \mathrm{~g}$ at $4^{\circ} \mathrm{C}$ for $10 \mathrm{~min}$ and the supernatant was stored at $-20^{\circ} \mathrm{C}$ until analysis. The reaction was done with an incubation volume of $80 \mu \mathrm{l}$, which consisted of $25 \mu \mathrm{l}$ supernatant, $20 \mu \mathrm{l}$ dithiothreitol $(80 \mathrm{mM}), 10 \mu \mathrm{l}$ morpholinopropanesulfonic acid buffer, $20 \mu \mathrm{l}$ unlabelled reverse T3 (3,3',5'-triiodo-L-thyronine, $12 \cdot 8 \mu \mathrm{M}$; Sigma Chemical Co.) and $5 \mu \mathrm{l}{ }^{125} \mathrm{I}$-labelled reverse T3 (12.8 $\mu \mathrm{M}, \mathrm{L}-3,3^{\prime}, 5^{\prime}$ triiodothyronine, $31 \mathrm{MBq} / \mu \mathrm{g}$; New England Nuclear Corp., Boston, MA, USA). Boiled liver homogenate was used as a reaction blank. After vortexing, the tubes were placed in a shaking waterbath $\left(37^{\circ} \mathrm{C}, 90\right.$ strokes $\left./ \mathrm{min}\right)$ for $15 \mathrm{~min}$. The reaction was terminated by adding $20 \mu \mathrm{l}$ of bovine serum albumin (40 g/l) (Sigma Chemical Co.), followed immediately by the addition of $150 \mu$ lice-cold TCA $(200 \mathrm{~g} / \mathrm{l})$. The tubes were held in ice-cold water for $15 \mathrm{~min}$, then total radioactivity was determined. After the determination, all the reaction solution was centrifuged at $4000 \mathrm{~g}$ at $-10^{\circ} \mathrm{C}$ for $30 \mathrm{~min}$, then $170 \mu \mathrm{l}$ supernatant was applied to an ion-exchange column (Dowex AG 50W-X8 $\left(\mathrm{H}^{+}\right)$; Bio-Rad Laboratories, Hercules, CA, USA), which was prewashed with $10 \mathrm{ml} 1.74 \mathrm{M}$-acetic acid. The ${ }^{125} \mathrm{I}$ was eluted with four $2 \mathrm{ml}$ aliquots of $1.74 \mathrm{M}$-acetic acid, and the radioactivity in the acetic-acid fraction was counted. The protein content of the liver homogenate was determined by the Lowry method (Lowry et al. 1951).

\section{Measurements of $N^{\tau}$-methylhistidine excretion rate}

The $\mathrm{MH}$ content of excreta samples was measured by the method of Hayashi et al. (1987) using HPLC. Dietary MH content was analysed similarly. The $\mathrm{MH}$ content of the experimental diet was $0.06 \mu \mathrm{mol} / \mathrm{g}$, and this was subtracted from the total excreted $\mathrm{MH}$. The rate of skeletal muscle protein breakdown was calculated by dividing the amount of excreted $\mathrm{MH}$ derived from skeletal muscle by the calculated amount of $\mathrm{MH}$ in the skeletal muscle using the method of Hayashi et al. (1985).

\section{Statistical analysis}

The results were analysed using Statview 4.11 (Abacus Concepts, Inc., Berkeley, CA, USA). One-way factorial ANOVA was applied and Fisher's PLSD (protected least significant difference) was selected for multiple comparison. Data are presented as means with their standard errors. Results were considered statistically significant at the $P<0.05$ level.

\section{Results \\ Experiment 1}

Results obtained in Experiment 1 are summarized in Fig. 1. Growth rates of the birds consuming Se-supplemented diets $(0.1,0.3$ or $0.5 \mathrm{mg} \mathrm{Se} / \mathrm{kg}$ diet $)$ were all greater compared with that of the Se-deficient birds, but significance $(P<$ 0.05 ) was observed only when the $0.5 \mathrm{mg} \mathrm{Se} / \mathrm{kg}$ diet was given (Fig. 1(a)). Dietary Se had no significant effect on feed intake and feed efficiency (Fig. 1(a)). The liver and plasma Se levels were significantly increased when birds were fed 0.3 or $0.5 \mathrm{mg} \mathrm{Se} / \mathrm{kg}$ diet. However, there were no significant differences between the birds fed $0 \cdot 1 \mathrm{mg} \mathrm{Se} / \mathrm{kg}$ diet and the Se-deficient diet (Fig. 1(b)). Se deficiency caused a significantly lower plasma T3 concentration and a higher plasma T4 concentration $(P<0.05$; Fig. 1(c)).

\section{Experiment 2}

Results obtained in Experiment 2 are summarized in Fig. 2. Se supplementation significantly $(P<0.05)$ improved the growth rates and feed efficiency as was shown in Experiment 1. However, the growth promoting effect of Se was not observed when iopanoic acid was given. The improvement in feed efficiency by Se supplementation was also halted by iopanoic acid (Fig. 2(a)). Plasma T4 concentration was significantly decreased $(P<0.05)$ by Se and this effect was negated by iopanoic acid (Fig. 2(b)). Plasma T3 concentrations were significantly higher in the Se group, and iopanoic acid neutralized the effects of Se. Se supplementation increased the hepatic $5^{\prime}$-ID activity and this increase was also negated by iopanoic acid (Fig. 2(c)).

\section{Experiment 3}

Results are shown in Fig. 3. The growth rate was higher than for the control diet when $0.3 \mathrm{mg} \mathrm{Se} / \mathrm{kg}$ diet was added. The growth rate was also improved by $0.1 \mathrm{mg} \mathrm{T} / \mathrm{kg}$ diet while the growth was retarded when $0.3 \mathrm{mg} \mathrm{T} 3 / \mathrm{kg}$ was 

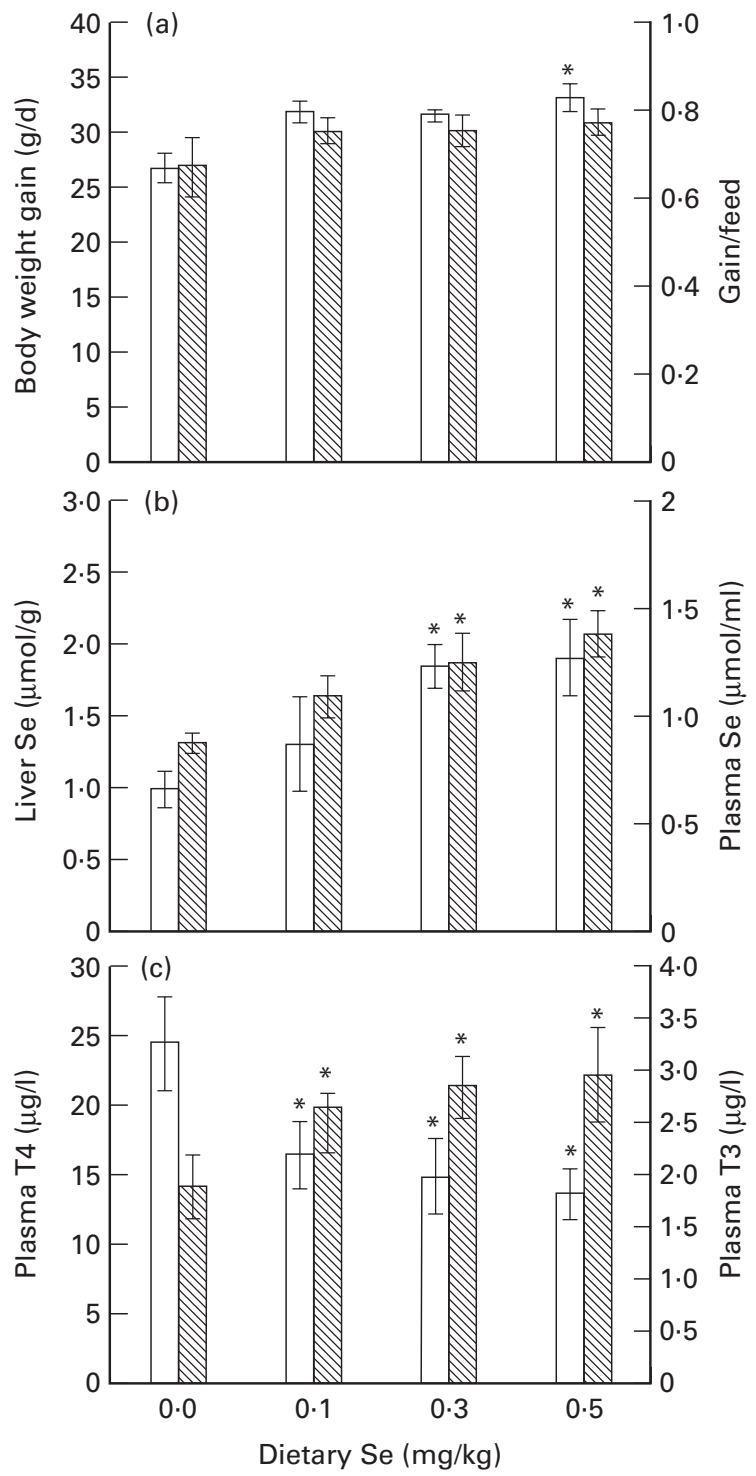

Fig. 1. Effects of dietary Se on (a), body-weight gain ( $\square$ ) and gain/ feed $(\mathbb{\mathbb { Q }})$, and (b), Se contents in liver $(\square)$ and plasma $(\mathbb{\mathbb { Q }})$, and (c), plasma concentrations of thyroxine (T4) ( $\square$ ) and 3,5,3'-triiodothyronine $(\mathrm{T} 3)(\mathbb{Q})$ in broiler chickens. For details of dietary composition see p. 728 and Table 1. Values are means for seven birds with their standard errors shown by vertical bars. Mean values were significantly different from the control $\left(0 \mathrm{mg} \mathrm{Se} / \mathrm{kg}\right.$ diet): ${ }^{\star} P<0.05$.

added. Both dietary Se and T3 had similar effects on feed efficiency (Fig. 3(a)). The supplementation of the diet with $0.1 \mathrm{mg} \mathrm{T} 3 / \mathrm{kg}$ caused a similar plasma T3 level as Se supplementation, while $0.3 \mathrm{mg} \mathrm{T} 3 / \mathrm{kg}$ diet caused a much higher plasma T3 level (Fig. 3(b)). Dietary T3 supplementation had a tendency to decrease the plasma T4 level (Fig. 3(b)). Se addition increased both hepatic 5'-ID activity and plasma GSHPx activity but dietary T3 supplementation had no significant effect on the activities of both enzymes (Fig. 3(c)). Dietary Se supplementation tended to increase the rate of skeletal muscle protein breakdown (Fig. 3(d)) indicating an increased muscle protein degradation due to increased plasma $\mathrm{T} 3$.
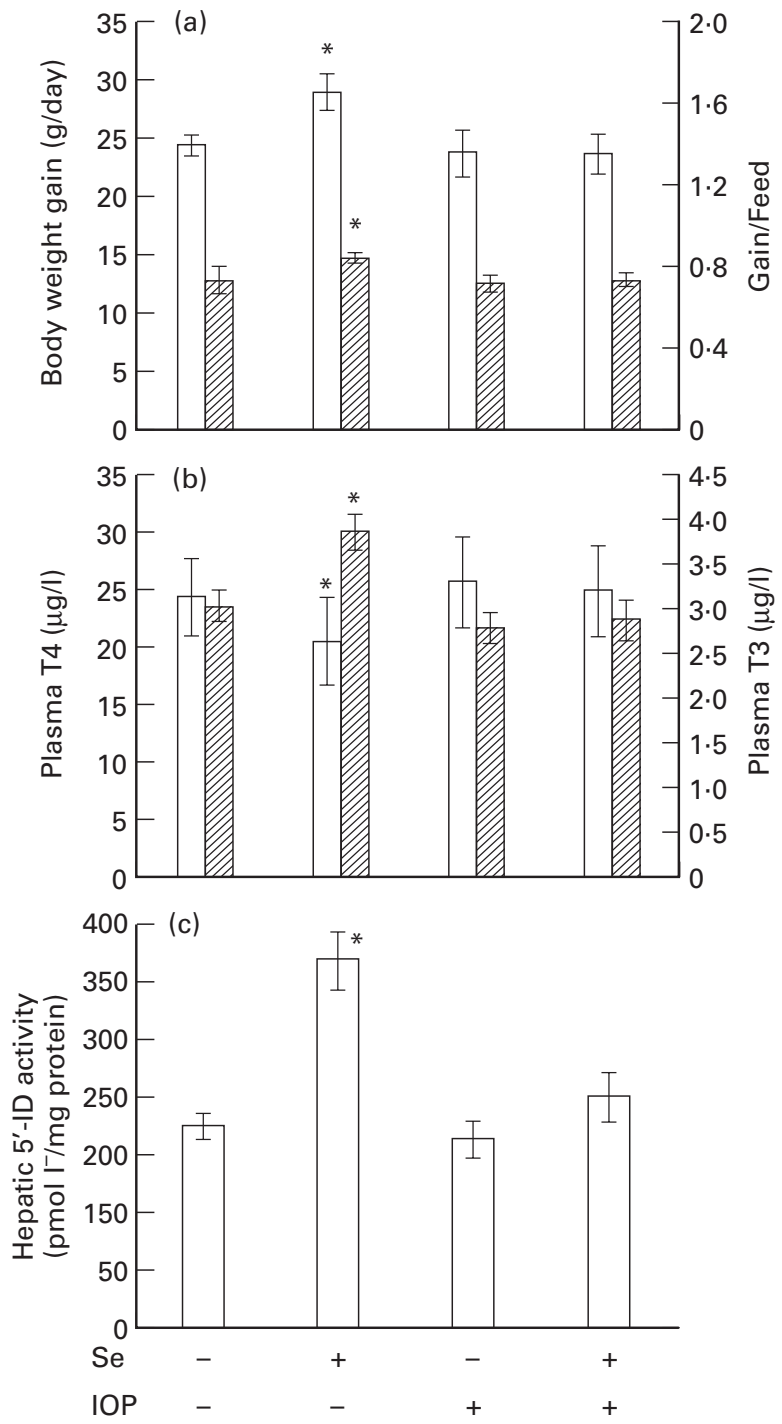

Fig. 2. Effects of dietary Se and iopanoic acid (IOP) on (a), bodyweight gain ( $\square$ ) and gain/feed ( $(\mathrm{C})$, and (b) plasma concentrations of thyroxine (T4) ( $\square$ ) and 3,5,3'-triiodothyronine (T3) (四), and (c), hepatic type I iodothyronine deiodinase (5'-ID) activity in broiler chickens. For details of dietary composition see p. 728 and Table 1. Values are means for seven birds with their standard errors shown by vertical bars. Mean values were significantly different from the control $(-\mathrm{Se},-\mathrm{IOP}):{ }^{*} P<0.05$.

\section{Discussion}

Although the present experiment was not designed to determine the recommended amount of dietary Se intake, the suitable dietary Se level is suggested to be about $0 \cdot 3 \mathrm{mg} / \mathrm{kg}$ diet, based on the analyses of plasma GSHPx activity and liver Se contents. Plasma Se concentration seemed to reach plateau at a highest supplementation level (about $0.5 \mathrm{mg} / \mathrm{kg}$ ). The suitable Se level suggested in the present experiment is higher than the National Research Council (1994) recommendation $(0.15 \mathrm{mg} / \mathrm{kg}$ diet), but corresponds with the US Food and Drug Administration allowance (Ullrey, 1992). However, hepatic 5'-ID activity could not be used for this purpose in the present experiment 

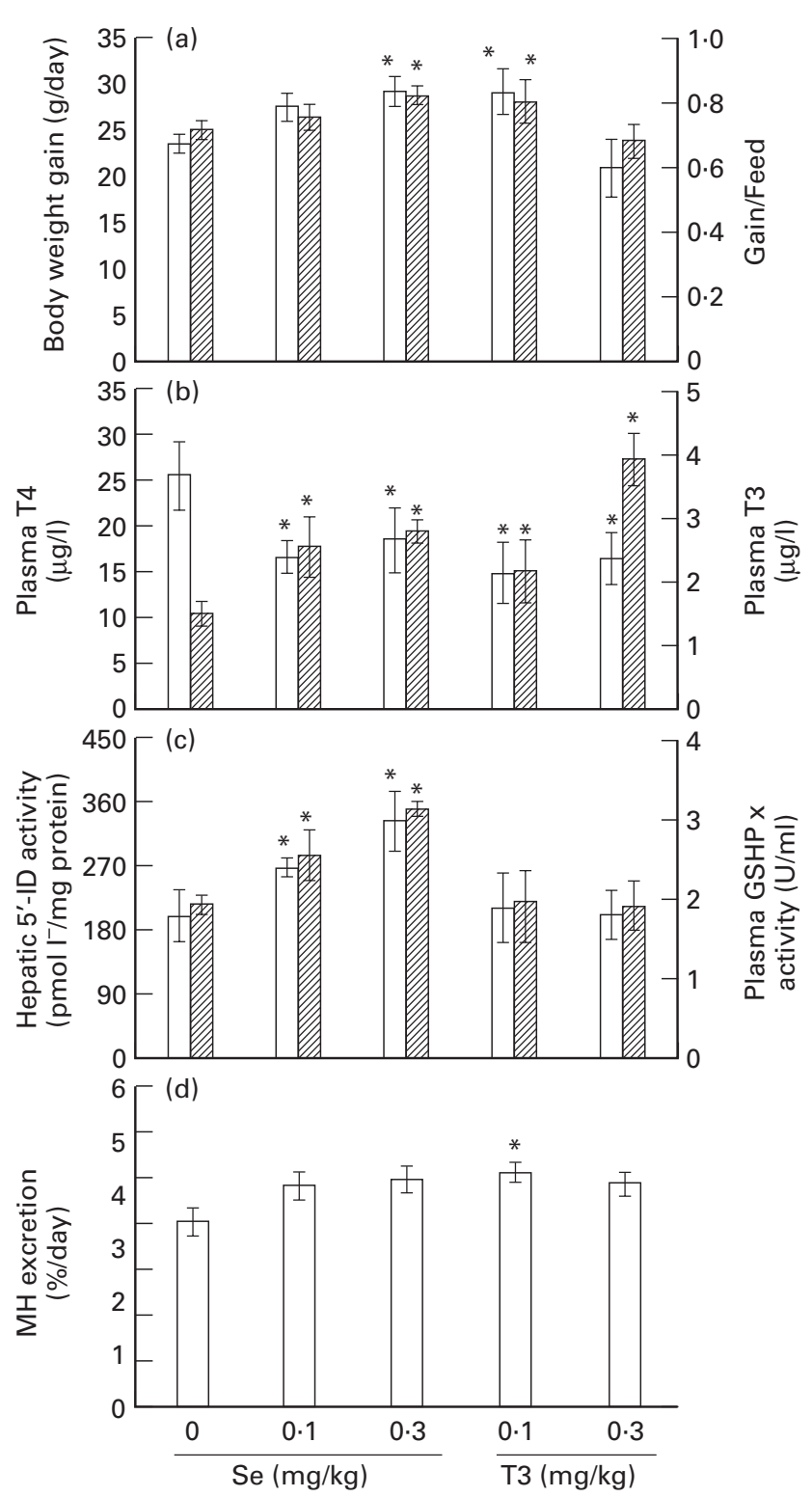

Fig. 3. Effects of dietary Se and 3,5,3'-triiodothyronine (T3) on (a),

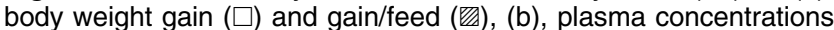
of thyroxine (T4) ( $\square$ ) and T3 (四) and (c), type I iodothyronine deiodinase $\left(5^{\prime}-I D\right)$ activity of liver $(\square)$ and gluathione peroxidase (GSHPx) (ש्Z) activity of plasma, and (d), rate of skeletal muscle protein breakdown as measured by $\mathrm{N}^{\tau}$-methylhistidine $(\mathrm{MH})$ excretion in broiler chickens. Values are means for seven birds, with their standard errors shown by vertical bars. Mean values were significantly different from the control $\left(0 \mathrm{mg} \mathrm{Se} / \mathrm{kg}\right.$ diet): ${ }^{*} P<0.05$.

because only four levels of Se, including the control, were examined, while hepatic 5'-ID activity significantly responded to the dietary Se levels.

Iopanoic acid, a specific monodeiodinase inhibitor (Harrison et al. 1996), depressed the hepatic 5'-ID activity when added to the Se-supplemented diet, and decreased the plasma T3 concentrations to the control levels. As expected, the growth promotion due to Se supplementation was completely halted by the addition of iopanoic acid (Fig. 2(a)), indicating that the growth promotion due to $\mathrm{Se}$ could relate to the hepatic 5'-ID activity.
More than thirty selenoproteins have been identified (Mitchell et al. 1996). Among them, GSHPx and iodothyronine deiodinase were shown to be functional selenoproteins. Se has long been believed to affect growth through the GSHPx activity. GSHPx plays a role in the detoxification of $\mathrm{H}_{2} \mathrm{O}_{2}$, which protects the cell from injury caused by peroxides. GSHPx activity continues to increase until the Se level has met the needs of the animal. However, it has also been shown that the relationship between GSHPx and growth is not simple (Jensen et al. 1986). It is possible that Se affects growth through the influence on $5^{\prime}$ ID activity. Thyroid function is known to be altered by many environmental factors, such as energy intake and dietary composition in addition to ambient temperature. Hypothyroidism may be induced by severe nutrient deficiency, high ambient temperature and anti-thyroidal substances. However, it is not yet clear whether thyroid hormone status induced by ambient temperature, nutrient deficiency etc., influences growth in animals. In the present study, we induced a reduction in plasma T3 concentration by both Se deficiency and administration of iopanoic acid. The impairment of hepatic 5'-ID activity followed by a decreased T3 production were clearly shown in the group of birds who were Se deficient and fed iopanoic acid. Both treatments caused clear growth depression.

Se deficiency caused a decrease of plasma T3 concentrations (Fig. 1(c)), and this might be a reason why growth was impaired in the Se-deficient birds. In fact, lower dietary T3 $(0.1 \mathrm{mg} / \mathrm{kg})$ stimulated the growth of Sedeficient birds. Growth impairment was also observed when iopanoic acid was given to the Se-fed birds. However, higher level of dietary T3 $(0.3 \mathrm{mg} / \mathrm{kg}$; catabolic dose) depressed the growth of birds as was expected. It is also important that dietary Se had a trend to increase the rate of skeletal muscle protein breakdown. It was shown that T3 increases the skeletal muscle protein breakdown rate in rats (Brown et al. 1981).

In conclusion, the present study strongly indicates that dietary Se improves the growth of broilers because Se is needed to synthesize $5^{\prime}$-ID which catalyses the conversion of $\mathrm{T} 4$ to $\mathrm{T} 3$.

\section{Acknowledgements}

The authors wish to thank Mr Yasuo Nishiyama for his assistance in measuring 5'-ID activity, Kagoshima Chicken Foods Co. Ltd (Kagoshima, Japan) for the kind supply of broiler chickens and Misses Rebecca Jill Sandiford and Ritsu Hayashi for correcting English and revising the manuscript.

\section{References}

Arthur JR \& Beckett GJ (1994) Roles of Selenium in Type I Iodothyromine $5^{\prime}$ Deiodimase and in Thyroid Hormone and Iodine Metabolism. In Selenium in Biology and Human Health, pp. 93-115 [RF Burk, editor]. New York, NY: Springer-Verlag.

Arthur JR, Nicol F \& Beckett GJ (1990) Hepatic iodothyronine 5'deiodinase. The role of selenium. Biochemical Journal 272, 537-540.

Arthur JR, Nicol F \& Beckett GJ (1992) The role of selenium in 
thyroid hormone metabolism and effects of selenium deficiency on thyroid hormone and iodine metabolism. Biological Trace Element Research 33, 37-42.

Arthur JR, Nicol F \& Beckett GJ (1993) Selenium deficiency, thyroid hormone metabolism, and thyroid hormone deiodinases. American Journal of Clinical Nutrition 57, Suppl., 236S-239S.

Beckett GJ, Beddows SE, Morrice PC, Nicol F \& Arthur JR (1987) Inhibition of hepatic deiodination of thyroxine is caused by selenium deficiency in rat. Biochemical Journal 248, 443-447.

Beckett GJ, Russell A, Nicol F, Sahu P, Wolf CR \& Arthur AR (1992) Effect of selenium deficiency on hepatic type I 5'iodothyronine deiodinase activity and hepatic thyroid hormone levels in rat. Biochemical Journal 282, 483-487.

Bellanger JR (1995) Adaption of a dry ashing for determination of selenium by fluorimetry in high-fat foods. Journal of the Association of Official Analytical Chemistry 78, 477-480.

Berry MJ, Banu L \& Larsen PR (1991) Type I iodothyronine deiodinase is a selenium containing enzyme. Nature 349, 438440.

Brown JG, Bates PC, Holliday MA \& Millward DJ (1981) Thyroid hormone and muscle protein turnover. The effect of thyroid-hormone deficiency and replacement in thyroidectomized and hypophysectomized rats. Biochemical Journal 194, $771-782$

Burk RF (1989) Recent development in trace element metabolism and function: newer roles of selenium in nutrition. Journal of Nutrition 119, 1051-1054.

Chanoine JP, Braverman LW, Farwell AP, Safran M, Alex S, Dubord S \& Leonard JK (1993) The thyroid gland is a major source of circulating $\mathrm{T}_{3}$ in the rat. Journal of Clinical Investigation 91, 2709-2713.

Davey JC, Becker KB, Schneider MJ, St-Germain DL \& Galton VA (1995) Cloning of a cDNA for the type II iodothyronine deiodinase. Journal of Biological Chemistry 270, 2678626789.

Freeman TB \& McNabb FMA (1991) Hepatic 5'-deiodinase activity of Japanese quail using reverse- $\mathrm{T}_{3}$ as substrate: Assay validation, characterization, and developmental studies. Journal of Experimental Zoology 258, 212-220.

Harrison AP, Tivey DR, Clausen T, Duchamp C \& Dauncey MJ (1996) Role of thyroid hormones in early postnatal development of skeletal muscle and its implications for undernutrition. British Journal of Nutrition 76, 841-855.
Hawkes WC \& Kimberly AC (1990) Automated continuous-flow colorimetric determination of glutathione peroxidase with dichloroindophenol. Analytical Biochemistry 186, 46-52.

Hayashi K (1993) Roles of thyroid hormone in growth and protein turnover. Animal Science and Technology 64, 938-947.

Hayashi K, Kirihara D \& Tomita Y (1991) Effect of experimental hypo- and hyperthyroidism on the rates of muscle protein synthesis and breakdown in cockerels. Animal Science and Technology 62, 109-113.

Hayashi K, Maeda Y, Toyomizu M \& Tomita Y (1987) Highperformance liquid chromatographic method for analysis of $\mathrm{N}^{\tau}$ methylhistidine in food, chicken excreta, and rats urine. Journal of Nutritional Science and Vitaminology 33, 151-156.

Hayashi K, Tomita Y, Maeda Y, Shinagawa Y, Inoue K \& Hashizume T (1985) The rate of degradation of myofibrillar proteins of skeletal muscle in broiler and layer chickens estimated by $\mathrm{N}^{\tau}$-methylhistidine in excreta. British Journal of Nutrition 54, 157-163.

Jensen LS, Colnago GL, Takahashi K \& Akiba Y (1986) Dietary selenium status and plasma thyroid hormones in chicks. Biological Trace Element Research 10, 11-18.

Kohrle J, Oertel M \& Gross M (1992) Selenium supply regulates thyroid function, thyroid hormones synthesis and metabolism by altering expression of the selenoenzymes type I $5^{\prime}$ deiodinase and glutathione peroxidase. Thyroidology 4, 1721.

Lowry OH, Rosebrought NJ, Farr AL \& Randall RJ (1951) Protein measurement with the Folin phenol reagent. Journal of Biological Chemistry 193, 265-275.

Mitchell JM, Nicol F, Beckett GJ \& Arthur JR (1996) Selenoenzyme expression in thyroid and liver of second generation selenium and iodine-deficient rats. Journal of Molecular Endocrinology 16, 259-267.

National Research Council (1994) In Nutrient Requirement of Poultry, 9th ed. Washington, DC: National Academy Press.

Paglia DE \& Valentine KJA (1967) Characterisation of erthyrocyte glutathione peroxidase. Journal of Laboratory and Clinical Medicine 70, 158.

Schwartz K, Foltz CM \& (1957) Selenium as an integral part of factor 3 against dietary necrotic liver degeneration. Journal of American Chemical Society 79, 3292-3293.

Ullrey DE, (1992) Basis for regulation of selenium supplements in animal diets. Journal of Animal Science 70, 3922-3927. 